\title{
APLIKASI STOCHASTIC PRODUCTION FRONTIER DALAM PENGUKURAN EFISIENSI TEKNIS BUDIDAYA UDANG VANAME DI JAWA TIMUR
}

\author{
Riski Agung Lestariadia,b,*, Lina Asmara Wati ${ }^{a}$ \\ ${ }^{\text {a} F a k u l t a s ~ P e r i k a n a n ~ d a n ~ I l m u ~ K e l a u t a n, ~ U n i v e r s i t a s ~ B r a w i j a y a, ~ J 1 ~ V e t e r a n, ~ M a l a n g, ~ I n d o n e s i a ~}$

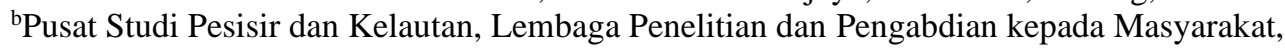 \\ Universitas Brawijaya, Jl Veteran, Malang, Indonesia \\ *Koresponden penulis : r.agung@ub.ac.id
}

\begin{abstract}
Abstrak
Penelitian ini bertujuan untuk menganalisis efisiensi teknis diantara petambak udang dengan menggunakan pendekatan stochastic frontier yang digabungkan dengan model efek inefisiensi. Data dikumpulkan dari 245 sampel petambak udang di Kabupaten Lamongan, Banyuwangi, dan Pacitan menggunakan kuesioner terstruktur. Hasil empiris menunjukkan bahwa tenaga kerja, pupuk, pakan buatan dan padat penebaran adalah faktor-faktor yang mempengaruhi variasi dalam output. Hasil analisis menunjukkan bahwa $68 \%(\gamma=0,68)$ kesalahan acak yang dihasilkan oleh model disebabkan oleh inefisiensi yang terjadi dalam proses produksi udang vaname. Skor efisiensi teknis petambak udang bervariasi, berkisar antara 0,77 - 0,97 dengan rata-rata 0,92 . Faktor-faktor yang mempengaruhi inefisiensi teknis dalam budidaya udang vaname di daerah penelitian diduga berasal dari atribut yang melekat pada petambak udang seperti umur, tingkat pendidikan, dan pengalaman dalam budidaya vaname
\end{abstract}

Kata kunci: Efisiensi teknis, Jawa Timur, Stochastic Production Frontier, Vaname

\begin{abstract}
The research aims to analyze the level of technical efficiency of shrimp farming using the stochastic frontier approach combined with the inefficiency effect model. Data were collected from 245 samples of shrimp farmers in Lamongan, Banyuwangi, and Pacitan using a structured questionnaire. Empirical results show that labour, fertilizer, artificial feed and stocking density are the factors that influence the variation in output. The results of the analysis show that $68 \%(\gamma=0.68)$ of random errors generated by the model are caused by inefficiencies that occur in the vannamei production process. The technical efficiency scores of shrimp farmers varied, ranging from $0.77-0.97$ with an average of 0.92 . Factors that influence technical inefficiency in vannamei shrimp culture in the study area are thought to come from attributes attached to shrimp farmers such as age, education level, and experience in shrimp cultivation.
\end{abstract}

Keywords: Technical efficiency, East Java, Stochastic Production Frontier, Vannamei

\section{PENDAHULUAN}

Budidaya perikanan memainkan peran penting dalam perekonomian Indonesia dalam upaya penyediaan lapangan pekerjaan, pendapatan dan mendukung ketahanan pangan [1][2][3]. Budidaya perikanan tumbuh cepat dengan rata-rata $25,62 \%$ dalam beberapa tahun terakhir. Pada tahun 2019, produksi budidaya perikanan dilaporkan mencapai mencapai 15,1 juta ton dengan nilai mancapai 66.5 Trilyun [4]. Total produksi ini telah menempatkan Indonesia pada peringkat ke-4 sebagai produsen budidaya perikanan terbesar, seteleh China, India, dan Vietnam [5].
Salah satu komoditas utama dan sumber investasi dalam budidaya perikanan adalah udang vaname. Produksi udang vaname meningkat secara signifikan dari 580,347 ton di tahun 2015, kemudian produksi di tahun 2019 dilaporkan mencapai 861,261 ton [6].

Budidaya udang memproduksi 59.8\% dari total produksi udang Indonesia. Lima propinsi produsen udang terbesar di Indonesia adalah Sumatera Selatan, Jawa Barat, Jawa Timur, Lampung dan Nusa Tenggara Barat. Sebagai salah satu produsen udang terbesar, Propinsi Jawa Timur menyumbang $12.6 \%$ dari total produksi udang dari sektor budidaya. Produksi udang di Jawa Timur tersebar di beberapa 
Kabupaten, dimana Kabupaten Situbondo, Kabupaten Gresik dan Kabupaten Lamongan sebagai produsen utama.

Petambak udang vaname di Jawa Timur didominasi oleh petambak skala kecil, dengan luas lahan kurang dari 5 hektar. Disisi lain, sebagian besar petambak udang di daerah tersebut menggunakan sistem intensif dalam budidaya udang. Sistem intensif dalam budidaya udang merupakan sistem budidaya dengan biaya tinggi. Pada proses produksi, petambak udang skala kecil seringkali dihadapkan pada permasalahan kelangkaan sumberdaya sebagai input produksi mereka, sebagai akibat dari keterbatasan modal. Salah satu faktor kunci dalam menjamin keberlajutan usaha budidaya udang vaname adalah tingkat efisiensi dalam proses produksi.

Oleh sebab itu, penelitian ini berusaha menganalisis tingkat efisiensi teknis diantara petambak udang vaname di Jawa Timur dengan menggunakan pendekatan Stochastic Frontier Analysis (SFA). Hasil analisis akan mengambarkan tingkat efisiensi teknis petambak udang vaname yang berguna dalam menjamin keberlanjutan kegiatan budidaya.

\section{METODE}

\section{Lokasi Penelitian}

Penelitian ini dilaksanakan di 3 Kabupaten di Jawa Timur, yaitu; Lamongan, Banyuwangi, dan Pacitan. Lokasi ini dipilih secara sengaja untuk merepresentasikan pesisir utara dan selatan Provinsi Jawa Timur. Sebanyak 245 petambak udang vaname dipilih sebagai sample dengan menggunakan metode simple random sampling. Data yang digunakan dalam penelitian ini berasal dari data aktivitas produksi pada masa panen kedua tahun 2020, yang dikumpulkan dengan menggunakan kuisioner terstruktur.

\section{Prosedur Estimasi dan Spesifikasi Model}

Berdasarkan Farrell [7], tingkat efisiensi teknis didefinisikan sebagai kemampuan dari perusahaan dalam menghasilkan output dengan sejumlah input yang tersedia. Tingkat efisiensi teknis dalam penelitian ini diukur dengan menggunakan pendekatan stochastic frontier yang pertama kali dikembangkan oleh
Aigner [8]. Pendekatan ini menggunakan estimasi fungsi frontier (batas), dimana setiap input yang digunakan dalam proses produksi mempunyai kapasitas optimal.

Fungsi produksi stochastic frontier didefinisikan sebagai:

Dimana:

$$
Y_{i}=f\left(X_{k i} ; \beta_{i}\right) \exp \left(\epsilon_{i}\right)
$$

$$
\begin{array}{ll}
Y_{i} & =\text { Output dari tambak ke } i \\
X_{k i} & =\text { Vektor input } k \text { dari tambak ke } i \\
\beta & =\text { Vektor dari parameter } \\
\epsilon_{i} & =\text { Kesalahan acak }
\end{array}
$$

Kesalahan acak yang terdapat di dalam model $\left(\epsilon_{i}\right)$ terdiri dari 2 komponen, atau disebut juga "composed error model" [9], yaitu:

$$
\epsilon_{i}=v_{i}+u_{i}
$$

Komponen $v_{i}$ adalah kesalahan acak yang merepresentasikan variasi dalam output dikarenakan faktor-faktor yang tidak dapat dikontrol, seperti penyakit udang dan cuaca, komponen ini diasumsikan sebarannya simetris dan menyebar normal $\left(v_{i} \sim N\left(0, \sigma_{v}^{2}\right)\right)$. Sedangkan $u_{i}$ merefleksikan inefisiensi teknis dari usaha budidaya vaname. Komponen ini diasumsikan sebarannya asimetris (one sided) yakni $u_{i} \geq 0$. Jika proses produksi berlangsung efisien, maka output yang dihasilkan akan berhimpit dengan potensi maksimumnya $\left(u_{i}=0\right)$. Sebaliknya, jika $u_{i} \leq$ 0 berarti berada di bawah potensi maksimum. Komponen ini diasumsikan iid, tidak bernilai negatif, berdistribusi setengah normal $\left.u_{i} \sigma \sim\left|N\left(0, \sigma_{u}^{2}\right)\right|\right)$ serta independen dari $v_{i}$ [10].

Metode Maximum Likelihood Estimation (MLE) dapat digunakan untuk menduga parameter $\beta$ dan $\lambda$. Dimana $\beta$ adalah vector dari parameter, sedangkan $\lambda$ didefinisikan sebagai:

$$
\lambda=\sigma_{u} / \sigma_{v} \text { dan } \sigma^{2}=\sigma_{v}^{2}+\sigma_{u}^{2}
$$

Battese dan Corra [11] mendefinisikan $\lambda$, sebagai total variasi output dari batasnya (frontier), yang berhubungan dengan efisiensi teknis, yaitu:

$$
\gamma=\frac{\sigma_{u}^{2}}{\sigma^{2}}
$$

Nilai dugaan $\gamma$ dapat diperoleh dari $\sigma^{2}$ dan $\lambda$. Sehingga nilai berkisar $\gamma$ antara $0 \leq \gamma \leq 1$.

Berdasarkan Battese dan Coelli [12], Kumbhakar dan Lovell [13], efisiensi teknis usaha budidaya vaname dari tambak ke $i$ dapat 
diukur dengan menggunakan persamaan berikut:

$$
T E_{i}=\frac{Y_{i}}{\exp \left(X_{i} \beta\right)}=\frac{\exp \left(X_{i} \beta-u_{i}\right)}{\exp \left(X_{i} \beta\right)}=\exp \left(-u_{i}\right)
$$

Tingkat efisiensi teknis untuk masingmasing tambak diperoleh dari hasil perbandingan tingkat aktual output, $Y_{i}$, dengan tingkat prediksi output, $\exp \left(X_{i}, \beta\right)$.

Spesifikasi fungsi produksi stochastic frontier untuk usaha budidaya vaname dalam peneltian ini didefinisikan sebagai:

$\ln Y_{i}=\beta_{0}+\beta_{1} \ln X_{1}+\beta_{2} \ln X_{2}+\beta_{3} \ln X_{3}+\beta_{4} \ln X_{4}$

Dimana $Y_{i}$ adalah jumlah output per hektar dari tambak ke $i, X_{1}$ adalah jumlah tenaga kerja (HOK per hektar), $X_{2}$ adalah jumlah pakan buatan yang diaplikasikan $(\mathrm{kg}$ per hektar), $X_{3}$ dan $X_{4}$ adalah jumlah pupuk (kg per hektar) dan benih udang vaname (ekor per hektar).

\section{HASIL DAN PEMBAHASAN}

Model fungsi produksi yang telah dirumuskan pada metode penelitian diduga dapat menggambarkan hubungan antara produksi dan input-input produksinya. Pendugaan fungsi produksi diperoleh dari data jumlah produksi udang vaname, penggunaan tenaga kerja, pakan buatan, pupuk dan tingkat kepadatan udang yang digunakan oleh petambak untuk 1 petak tambak dalam satu kali proses produksi.

Pendugaan parameter fungsi produksi stochastic frontier dengan dilakukan dalam dua tahap, tahap pertama dengan menggunakan metode Ordinary Least Square (OLS) untuk memberikan gambaran kinerja rata-rata (best fit) dari proses produksi tambak udang vaname pada tingkat teknologi yang digunakan. Tahap kedua, pendugaan parameter menggunakan metode Maximum Likelihood Estimation (MLE) untuk memberikan gambaran kinerja terbaik (best practice) dari usaha budidaya udang vaname di daerah penelitian.

Hasil pendugaan parameter dengan menggunakan metode OLS dan MLE pada Tabel 1 menunjukkan bahwa variabel tenaga kerja, pakan buatan, pupuk dan tingkat kepadatan berpengaruh nyata terhadap produksi udang vaname dengan $\alpha=1 \%$. Hasil penjumlahan dari nilai elastisitas produksi yang dihasilkan $(1,162)$ menunjukkan bahwa produksi udang vaname di daerah penelitian berada pada kondisi Increasing Return to Scale, dimana penambahan input sebanyak $1 \%$ akan meningkatkan output sebanyak $1,162 \%$.

Table 1. Hasil Analisis OLS dan MLE

\begin{tabular}{|c|c|c|}
\hline Variabel & $\begin{array}{l}\text { Ordinary } \\
\text { Least } \\
\text { Square } \\
\text { (OLS) }\end{array}$ & $\begin{array}{l}\text { Maximum } \\
\text { Likelihood } \\
\text { (MLE) }\end{array}$ \\
\hline Konstanta & $\begin{array}{c}- \\
10,123\end{array}$ & $-10,132$ \\
\hline Ln Tenaga Kerja & $0,165^{\mathrm{a}}$ & $0,166^{\mathrm{a}}$ \\
\hline Ln Pakan buatan & $0,106^{\mathrm{a}}$ & $0,117^{\mathrm{a}}$ \\
\hline Ln Pupuk & $0,589^{\mathrm{a}}$ & $0,598^{\mathrm{a}}$ \\
\hline $\begin{array}{l}\text { Ln Kepadatan benih } \\
\mathrm{R}^{2}\end{array}$ & $\begin{array}{l}0,302^{\mathrm{a}} \\
91,89\end{array}$ & $0,315^{\mathrm{a}}$ \\
\hline $\begin{array}{l}\lambda=\sigma_{v} / \sigma_{u} \\
\sigma=\sqrt{\sigma^{2}+\sigma^{2}}\end{array}$ & & $\begin{array}{l}1,454^{\mathrm{a}} \\
0.125^{\mathrm{a}}\end{array}$ \\
\hline $\begin{array}{l}\sigma=\sqrt{\sigma_{u}^{2}}+\sigma_{v}^{2} \\
\sigma_{v}^{2} \\
\sigma_{u}^{2} \\
\text { Log Likelihood }\end{array}$ & & $\begin{array}{l}0,125^{a} \\
0,0049 \\
0,0105 \\
119,210\end{array}$ \\
\hline
\end{tabular}

Analisis di Tabel 1 menunjukkan bahwa estimasi parameter antara metode OLS dan MLE menghasilkan parameter yang sedikit berbeda, baik untuk konstanta dan koefisien regresi. Perbedaan ini dapat disebabkan karena metode MLE menghasilkan estimasi fungsi frontir (batas), dimana setiap input yang digunakan dalam proses produksi diestimasi kapasitas optimalnya. Selain itu, perbedaan antara OLS dan MLE dapat dilihat dari nilai $\lambda$ yang menggambarkan tingkat perbedaan antara fungsi produksi tersebut. Nilai $\lambda$ juga menunjukkan adanya inefisiensi teknis dalam produksi udang vaname di daerah penelitian.

Hasil analisis untuk variasi kesalahan acak antara $\sigma_{u}^{2}$ dan $\sigma_{v}^{2}$ adalah 0,0049 dan 0,0105. Hasil ini menunjukkan bahwa kesalahan acak yang dihasil oleh model lebih besar dipengaruhi oleh inefisiensi teknis, dibandingkan dengan kesalahan acak yang dapat disebabkan oleh faktor-faktor yang tidak dapat dikontrol oleh petambak (seperti penyakit udang dan cuaca). Selain itu, Battese dan Cora [11] menjelaskan bahwa total variasi dari kesalahan acak yang disebabkan oleh inefisiensi dapat dilihat dari parameter $\gamma$ $\left(\sigma_{u}^{2} / \sigma^{2}\right)$. Hasil analisis menunjukkan bahwa $68 \% \quad(\gamma=0,68) \quad$ kesalahan acak yang 
dihasilkan oleh model disebabkan oleh inefisiensi yang terjadi dalam proses produksi udang vaname.

Tingkat efisiensi teknis pada usaha budidaya vaname di lokasi penelitian dapat dilihat pada Tabel 2. Tingkat efisiensi teknis usaha budidaya vaname berkisar antara 0,77 sampai dengan 0,97, dengan efisiensi teknis rata-rata sebesar 0,92. Hasil analisis ini memberikan informasi bahwa efisiensi dalam produksi vaname diantara petambak dapat ditingkatkan sebesar $8 \%$ dengan pengunaan input dan tingkat teknologi yang ada.

Table 2. Hasil Analisis Efisiensi Teknis

\begin{tabular}{lcc}
\hline $\begin{array}{l}\text { Efisiensi } \\
\text { Teknis }\end{array}$ & $\begin{array}{l}\text { Jumlah } \\
\text { Petambak } \\
\text { Udang }\end{array}$ & Persentase \\
\hline $0,70-0,79$ & 4 & 1,6 \\
$0,80-0,89$ & 57 & 23,2 \\
$0,90-1,00$ & 184 & 75,2 \\
$\quad$ Total & 245 & 100 \\
Rata-rata & & 0,92 \\
Efisiensi & & \\
Teknis & & \\
\hline
\end{tabular}

Mayoritas petambak udang vaname di daerah penelitian $(75,2 \%)$ memiliki tingkat efisiensi yang tinggi (antara $0,90-1,00$ ). Perbedaan tingkat efisiensi teknis diantara petambak udang vaname mengindikasikan tingkat penguasaan dan penerapan teknologi budidaya udang vaname yang hampir seragam. Hal ini dimungkinkan karena adanya kerjasama antara kelompok petambak udang dengan salah satu perusahaan pakan udang dalam bentuk bimbingan teknis budidaya vaname yang sudah mulai dilakukan sejak tahun 2003.

Faktor-faktor yang mempengaruhi inefisiensi teknis dalam budidaya udang vaname di daerah penelitian diduga berasal dari atribut yang melekat pada petambak udang seperti umur, tingkat pendidikan, pengalaman dalam budidaya vaname, dan faktor eksternal seperti minimnya kunjungan dari penyuluh perikanan dan pelatihan teknis dalam budidaya vaname.

\section{KESIMPULAN}

Penelitian ini menggunakan pendekatan Stochastic Frontier dengan metode Maximum Likelihood untuk mengukur tingkat efisiensi teknis diantara petambak udang vaname di beberapa lokasi penelitian. Hasil penelitian menunjukkan bahwa tingkat efisiensi teknis yang dicapai oleh petambak udang vaname di daerah penelitian bervariasi, berkisar antara 0,77 sampai dengan 0,97 , dengan tingkat efisiensi teknis rata-rata sebesar 0,92 . Hal ini menunjukkan bahwa petambak udang vaname telah mencapai tingkat efisiensi teknis yang relatif tinggi, dan masih dimungkinkan untuk meningkatkan produksi sebesar $8 \%$ dengan penggunaan input produksi dan tingkat teknologi yang ada.

Upaya peningkatan efisiensi teknis budidaya udang vanname dapat dilakukan dengan cara peningkatan kemampuan teknis budidaya dari para petambak udang di daerah penelitian. Implikasi kebijakan dari hasil penelitian ini adalah; 1) diperlukan dukungan dari Pemerintah berkaitan dengan pelatihan teknis budidaya udang vaname, pencegahan dan penanggulangan penyakit udang serta manajemen usaha budidaya udang vaname. 2) diperlukan bimbingan teknis yang rutin dan berkelanjutan dari petugas penyuluh perikanan di daerah penelitian sehingga setiap permasalahan teknis budidaya udang yang muncul dapat segera diatasi.

\section{UCAPAN TERIMA KASIH}

Penulis mengucapkan terimakasih kepada Tim Peneliti di Pusat Studi Pesisir dan Kelautan, Universitas Brawijaya yang telah banyak membantu selama pelaksanaan penelitian ini.

\section{DAFTAR PUSTAKA}

[1] Amelia, F., Yustiati, A., \& Andriani, Y. (2021). Review of Shrimp (Litopenaeus vannamei (Boone, 1931)) Farming in Indonesia: Management Operating and Development. 158, 145-158.

[2] Elfitasari, T., \& Albert, A. (2017). Challenges encountered by small scale 
fish farmers in assuring fish product sustainability. Omni-Akuatika, 13(2).

[3] Nurdjana, M. L. (2006, December). Indonesian aquaculture development. In International Workshop on Innovative Technologies for Eco-Friendly Fish Farm Management and Production on Safe Aquaculture Food. Bali.

[4] KKP (2019). Statistik Perikanan dan Kelautan. Kementrian Kelautan dan Perikanan Republik Indonesia. Jakarta.

[5] FAO. (2019). The State of World Fisheries and Aquaculture. Roma.

[6] Sidatik KKP (2021). Sistem Informasi Diseminasi Data dan Statistik Kelautan dan Perikanan 2021. Kementerian Kelautan dan Perikanan (KKP), Republik Indonesia.

[7] Farrell, M. J. (1957). The Measurement of Productive Efficiency. Journal of the Royal Statistical Society, 253-290

[8] Aigner, D. L. (1977). Formulation and Estimation of Stochastic Frontier Production Estimation Models. Journal of Econometrics , 21-37.
[9] Meeusen, W. dan J. van den Broeck. (1977). Efficiency Estimation from Cobb-Douglas Production Function with Composed Error. International Economic Review. 18:435-444.

[10] Coelli, T.J., Prasada Rao, D.S., and Battese, G.E. (1998). An Introduction to Efficiency and Productivity Analysis. Dordrecht: Kluwer Academic Publishers Group.

[11] Battese, G. E., Corra, G. S. (1977), Estimation of a Production Frontier Model: with Application to the Pastoral Zone of Eastern Australia. Australian Journal of Agricultural Economics. No 21. Vol. 3. 169-179.

[12] Battese, G. E., dan Coelli, T. J. 1988. Prediction of Firm-Level Technical Efficiencies: with a Generalized Frontier Production Function and Panel Data. Journal of Econometrics 38, 387-399.

[13] Kumbhakar, S. C. dan C.A.K. Lovell. (2000). Stochastic Frontier Analysis. Cambridge University Press, Cambridge. 